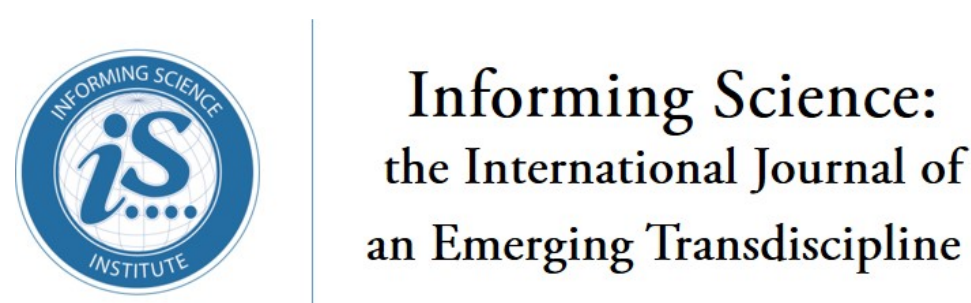

An Official Publication

of the Informing Science Institute

InformingScience.org

Inform.nu

Volume 22, 2019

\title{
The KGB ANd ANTI-IsRael Propaganda Operations
}

Eli Cohen*

Elizabeth Boyd

* Corresponding author
Informing Science Institute

Informing Science Institute
EliCohen@InformingScience.org

BettyBoyd@InformingScience.org

\section{ABSTRACT}

Aim/Purpose The paper explores the success of KGB Operation SIG to incite hatred and create chaos against a democracy

Background About 50 years ago, the KGB created the means to create upheaval in the Middle East. This paper explores one such campaign and its successor campaign, revealing some disinformation techniques in use today.

Methodology The paper brings together literature from many fields in its exploration of Operation SIG.

Contribution The paper reveals the role of the KGB in the PLO's campaign to replace Israel with an Arab Muslim state and the PLO and Hamas's successor disinformation mechanisms.

Findings Operation SIG is an early and extremely successful example of the Soviet/Russian campaign to disrupt democracy.

Impact on

Society

The recurrence of antisemitism, particularly on campus, can be attributed to Operation SIG.

Keywords informing science, bias, misinformation, disinformation, propaganda, fake news, deception, Russia, Operation SIG, PLO, Nazi, Israel, KGB

When academics encounter a new idea that doesn't conform to their preconceptions, there's often a sequence of three reactions: first dismiss, then reject, and finally declare it is obvious

(Sloman \& Fernbach, 2018, p. 255).

The revelations in this paper may initially elicit disbelief by some. Much of the Informing Science Literature is abstract and, for this reason, difficult to apply to real-world situations, particularly complex ones. This paper summarizes in a single paper a real-world situation of KGB interference with a democracy, using evidence drawn from diverse fields. The facts are well documented but not well known in any single discipline. In this sense, it is transdisciplinary.

Cite as: Cohen, E. \& Boyd, E. (2019). The KGB and anti-Israel propaganda operations. Informing Science: The International Journal of an Emerging Transdiscipline, 22, 157-182. https://doi.org/10.28945/4488

An earlier version of this paper was published in the Proceedings of the Informing Science and Information Technology Education Conference, Jerusalem, Israel. https://doi.org/10.28945/4357

(CC BY-NC 4.0) This article is licensed to you under a Creative Commons Attribution-NonCommercial 4.0 International License. When you copy and redistribute this paper in full or in part, you need to provide proper attribution to it to ensure that others can later locate this work (and to ensure that others do not accuse you of plagiarism). You may (and we encourage you to) adapt, remix, transform, and build upon the material for any non-commercial purposes. This license does not permit you to use this material for commercial purposes. 
Many people today feel comfortable expressing beliefs that others view as antisemitic. On campuses in rallies, and even in some houses of worship, Jews are called the new Nazis. When and how did these memes make their way into popular consciousness and, more importantly, who initiated this trend and why? Did a Moscow-created disinformation operation, starting a half-century ago, plant the seed that grew into today's virulent antisemitism? This paper endeavors to provide some thoughts on this matter by describing such a campaign, Operation SIG.

\section{BACKGROUND}

\section{WHAT IS OPERATION SIG?}

Operation SIG is the KGB operation to sow worldwide disapproval for the US and Israel. SIG is the Russian acronym for Sionistskiye Gosudarstva, or "Jewish (or Zionist) Government." The operation started shortly after 1967, when the drive for Arab unity collapsed along with the economies of the armies that attacked Israel (Shlaim, 2003). Wikipedia's anonymous entry on Soviet terrorism lists the operation's start as a few years later. We quote it below for completeness.

"After defeat of Soviet-controlled Arab states in the 1967 Six-Day war, the Soviet Union started a widespread undercover campaign against Israel, involving propaganda as well as direct military support (funding, arms, training) to terrorist groups declaring Israel as their enemy. Additionally, the USSR took the decision to increase anti-Israeli sentiment by disseminating anti-Zionist propaganda and even referencing previous anti-Semitic tropes from Western culture ... The overall goal of the campaign was to spread the idea that the state of Israel was an oppressive, imperialist state which was built on unjust terms operation "SIG" ("Zionist Governments") that was devised in 1972 to turn the Arab world against Israel and the United States" ("Terrorism and the Soviet Union," n.d.).

Hazan (2017) writes, "At its core, the Soviet anti-Zionist campaign of 1967-1988 was a campaign of propaganda and disinformation. It built and weaponized narratives based on made-up or twisted facts. It distorted history. It employed classic propaganda tools such as deception, guilt by association, and repetition to inculcate the key messages. It shamelessly played on people's sentiments, and it used both Soviet Jews and Muslims as instruments of propaganda."

Operation SIG created the cover for antisemites and antidemocratic forces, thus fulfilling the KGB's ambition to create chaos in the Middle East. That cover relies on the ignorance of history and facts. The Media Research Center reported that news host Bill Maher recently took his fellow media colleagues to task for ignoring history, facts, and antisemitism saying they "actually slept through history class." He reminded his journalist colleagues that Saudi Arabia bars Jews from even entering the country and noted the high number of Jews expelled from Muslim countries of birth (Wilmouth, 2019).

\section{Sources}

Wherever possible, this paper quotes the actual words of those KGB agents who created and led the KGB's anti-Israel campaign, Operation SIG, the topic of this paper. Those agents include Lt. Gen. Ion Mihai Pacepa, Major Anatoliy Mikhaylovich Golitsyn, Major Vasily Mitrokhin, Colonel Alexander Mikhailovich Orlov, and Czech Intelligence Officer Ladislav Bittman. When KGB archivist Mitrokhin defected from the USSR in 1992, he brought with him some 25,000 pages of secret KGB archives, showing not only the identities of KGB spies in the US, Britain, and elsewhere but also details on a large number of secret KGB operations around the world, including Operation SIG. This paper cites relevant portions of these archives (Mitrokhin, 2004). 


\section{WHERE: DISINFORMATION CAMPAIGNS ARE BOTH OLD AND NEW}

Russia is not the only country to manipulate social media. Countries use fake news as part of their propaganda and disinformation campaigns. As seen in Figure 1, the disturbing phenomenon is worldwide.

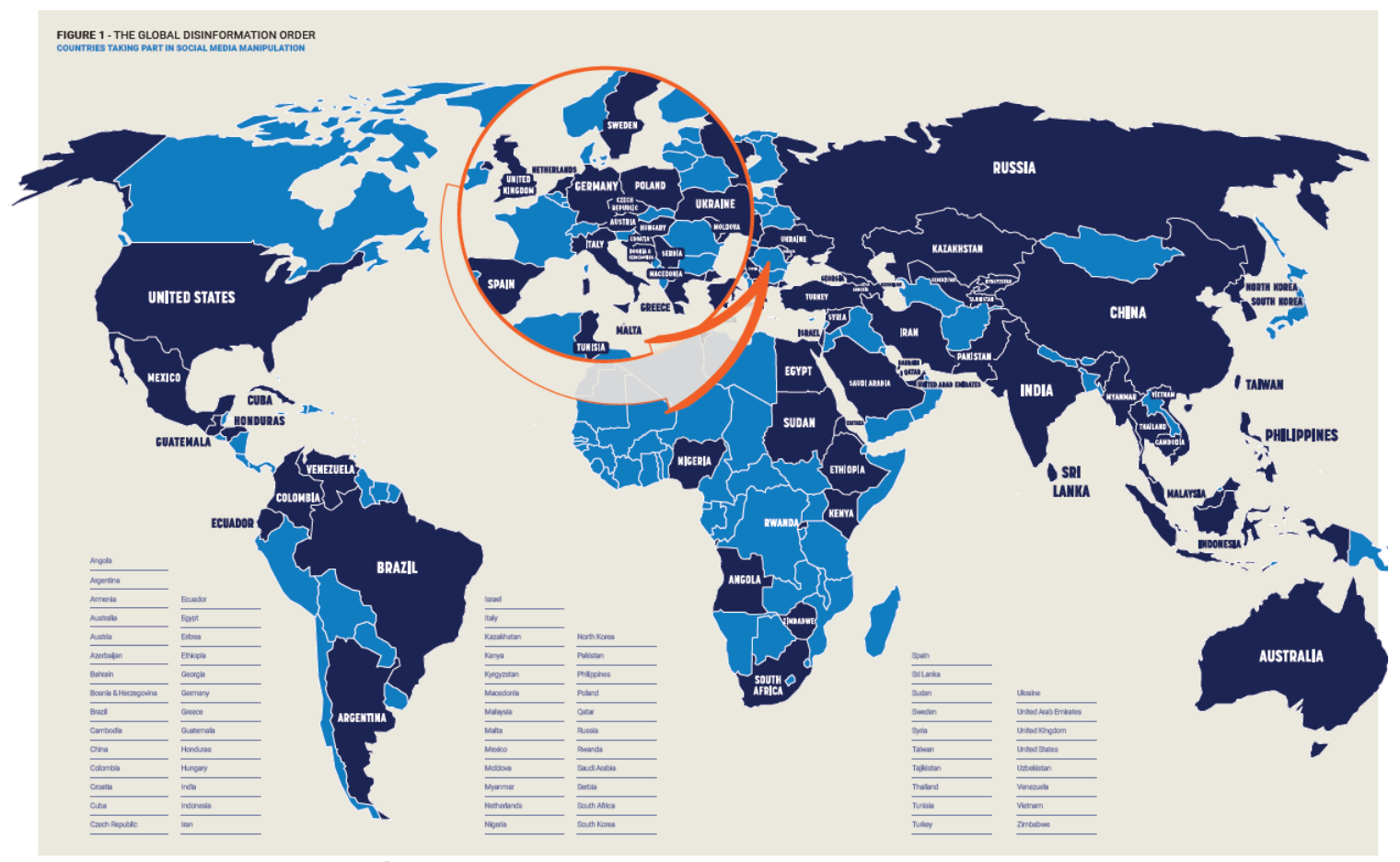

Figure 1. Countries contributing to social media manipulation.

(Source: Bradshaw \& Howard, 2019)

However, Russia's meddling efforts are well established and extensive. In recent years, the media began reporting on Russian successes in fomenting hatred and division in the US, Lithuania, Estonia, Cyprus, Bulgaria, Hungary, Greece, Italy, Denmark, Macedonia, United Kingdom, Poland, Czech Republic, Belarus, Germany, Spain, Finland, Canada, Turkey, Ukraine, Montenegro, Moldova, Indonesia, Brazil, France, Georgia, and others (Bisen, 2019; Collins, 2012; Dorell, 2017; Ellick \& Westbrook, 2018; Gricius, 2019; Mintz, 2012; Nance, 2016; Stanley, 2015). However, these reports are fragmented and fail to portray the big picture of a long-term global set of disinformation campaigns to advance Moscow's interests at the expense of others.

The tools in Moscow's disinformation playbook aim to strengthen its hand by sowing conflict and discontent within and between nations around the world. That playbook includes fighting democracies through a war on truth as well as recruiting, organizing, and training insurgents for terrorism and insurgency. KGB General Aleksandr Sakharovsky said: "In today's world when nuclear arms have made military force obsolete, terrorism should become our main weapon" (Pacepa, 2006.) This paper on disinformation reveals an early and perhaps the world's most successful hidden war on democracy.

\section{WHAT: CREATING AGENTS OF CHAOS}

The extent of the Kremlin's Program. In 2018, the US indicted 12 Russian intelligence officers for interfering in its 2016 elections (Mazzetti \& Benner, 2018). However, the number involved in organizing disinformation is likely vastly greater. During the Soviet era, Moscow ran up to 15,000 agents operating disinformation campaigns throughout the world (Ellick, quoted in Gross, 2018). 
A report by Mark Galeotti (2017) for the European Council on Foreign Relations describes the multi-faceted way Russian President and former KGB chief Vladimir Putin now employs active measures to advance Russia's agenda. See Figure 2.

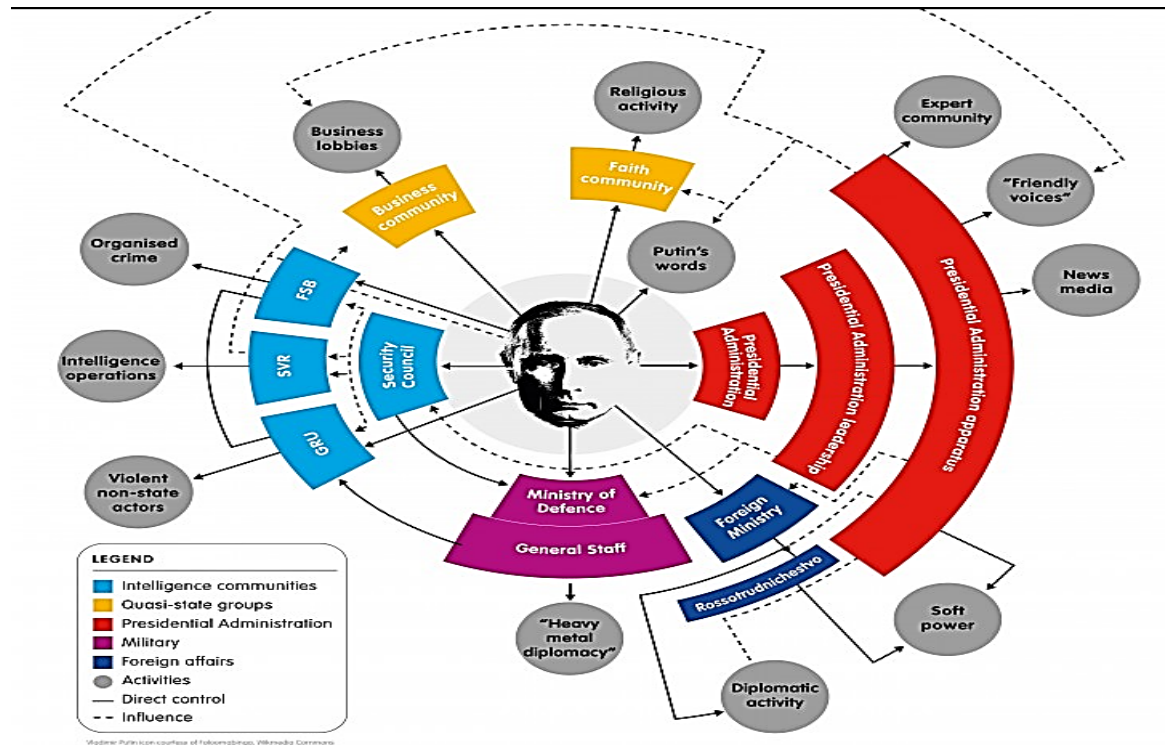

Figure 2. How Putin Coordinates Russia's Active Measures. (Source: Galeotti, 2017)

Active Measures, Reflexive Control, and Hybrid Warfare. The term "active measures" refers to Soviet and Russian political warfare. Ronen Bergman (2016) writes that the KGB defined active measures as "operations carried out by agents or fighters, meant ... to solve international problems, deceive rivals, weaken their status and disrupt their ability to successfully execute hostile (to the Soviet Union) plans." Żaryn (2019), writing in Defense News about Russia's current activities against Poland, uses the term "hybrid warfare" to denote Russia's uses of active measures to undermine relations both within a country and with its neighbors. He uses hybrid warfare to include not just propaganda but also the use of journalists to disseminate false information, and military or paramilitary action.

Thomas (2004) uses the term reflexive control to refer to interfering with the decision-making process of those whom you wish to control: "specially prepared information to incline bim to voluntarily make the predetermined decision desired by the initiator of the action" and "to 'control' the 'reflex' of the opponent by creating a certain model of behavior in the system it seeks to control. The most fundamental way to do this is to locate the weak link in the system and exploit it through moral arguments, psychological tactics, or appeals to specific leaders' character" (p. 237).

The Russian disinformation service is well developed, financed, and researched. Thomas (2004) points out that Russia even created an academic journal to disseminate its research on this topic and its techniques. While the journal itself is relatively new, the Russian military has been heavily involved in deception for over a century. Thomas writes that as early as 1904, Russia used as tools of war maskirovka (deception) and misinformation, including creating a Higher School of Maskirovka (College of Deception) to develop and advance such concepts. Joseph Stalin even coined the term "disinformation" (Аезинформация) as he set up a tactical office, later moved to the KGB, to deliberately mislead audiences, both within the USSR and more importantly in other nations (Golitsyn, 1984; Jowett \& O’Donnell, 2005, pp. 21-23; Manning \& Romerstein, 2004, pp 82-83; Pacepa \& Rychlak, 2013; Schoen \& Lamb, 2012; Taylor, 2016).

Here is a timeline leading up to the topic of this paper, Operation SIG:

- One hundred years ago - Stalin coins the term disinformation, sets up a tactical office to create agents of chaos (Agitprop); organizes guerilla armies in Spain, Ukraine 
- Seventy years ago -the start of organizing "peace" movements in the West to weaken democracies (e.g., World Peace Council) using well-meaning "useful idiots."

- Fifty years ago - KGB creates Operation SIG with the purpose "to instill a Nari-style hatred for the Jews throughout the Islamic world, and to turn this weapon of the emotions into a terrorist bloodbath against Israel' (Pacepa, 2006).

\section{HOW DISINFORMATION IS CREATED AND DISSEMINATED}

While much attention in recent days has been on the use of social media to disseminate disinformation, the Russian active measures are much broader. They include also planting fake news stories in mass media (newspapers and TV), cyber-attacks, and infiltrating into social movements, such as the Women's Movement. The goal is to create disruption, dissension, and chaos. Another paper in this series (Cohen, 2019]) outlines the principles and tactics for deception. However, the Russian efforts to produce chaos extend well beyond just manipulating media.

Puppet foreign guerilla armies. One of the active measures to overturn democracies employed recruiting, training, and outfitting locals into guerrilla armies. The countries included Bolivia, Columbia, Italy, Armenia, Ireland, Germany, Canada, the United Kingdom, as well as Israel ("Terrorism and the Soviet Union," n.d.). More recently, Ukraine has reported that Russia did the same.

Media and Cyber. In the past, the most pressing fear of nations has been physical attacks. In recent years, fighting cyber-attacks by other nations has become a concern (Clarke \& Knake, 2010). Currently, nations are becoming aware of another danger, the use of media and psychologic warfare to spread misinformation and propaganda. Peter Pomerantsev (2019) writes, "W ar used to be about capturing territory and planting flags," but now the war is about propaganda, perhaps even more than using armies to inflict harm on adversaries. He writes that propaganda, its lies, and half-truths, threaten democracy. In his 2014 paper published in Foreign Policy, Pomerantsev writes of Russian efforts against Ukraine as if that campaign was something new, but as we shall see, the playbook is an old one.

Many papers explored in great depth the role of the Soviets in influencing elections; see, e.g., Mueller's (2019) report on Russian interference in the US 2016 election. Time Magazine reported on recent Russia's social media attacks on American democracy (Calabresi, 2017), and the New Republic reported on Russian disinformation attacks on Ukraine (Cain, 2019). These and other campaigns by Russians have been exposed elsewhere (Engel, 2019).

Paul Goble (2019) reports that almost a century ago, on January 11, 1923, 13 days after the establishment of the USSR, it conducted its first disinformation campaign. In that case, the operation was internal. The highly successful KGB campaign described in this paper, Operation SIG, is the now 50plus-years-old. That Russian campaign's goal was to enlist Middle East agitators to create hatred against Jews, Israel, and the USA.

Many of the techniques perfected by the KGB then are still in use by the Kremlin and its actors (Pomerantsev \& Weiss, 2014). These techniques also are in widespread use by other governments (Pomerantsev, 2019). Figure 1 shows the spread of these disinformation techniques (using social media by governments) worldwide.

Let us note in passing that others, organizations and individuals seeking personal profit, use some of these same techniques of disinformation (Holiday, 2013; "The Quarter Billion Dollar Question," 2019) and partisan political gains (Center for Media, Data and Society, n.d.; Mayer, 2017; Wardle, 2017). 


\title{
WHY AND WHEN: IMPETUS FOR OPERATION SIG
}

In 1948, as Israel declared independence, the armies of five Arab nations attacked the new nation. The USSR's Joseph Stalin, hopeful that Israel's socialist roots would lead it to join the Communist bloc, instructed a country it controlled, Czechoslovakia, to provide Israel with the arms needed for defense. However, upon later learning of Stalin's murder of 20 million people, Israeli society rejected communism. As a result, Moscow shifted its support to Arab dictatorships (Gordis, 2019, pp. 214215). Arab nations became increasingly dependent on Moscow's weapons and military training. The KGB recruited Arab agents to head up a guerilla army and propaganda campaign. In 1967, when the armies of Soviet-supported Arab countries failed to conquer Israel, this Operation SIG became Moscow's primary means for advancing chaos in the Middle East against the Israeli democracy.

\section{HOW: OPERATION SIG TACTICS}

\author{
"We have yet to understand fully how Soviet anti-Zionist propaganda influenced the world. In \\ those individual instances where this influence is evident, it is apparent just how negatively it \\ impacted the lives of Jews around the globe." (Tabarovsky, 2019).
}

Even before former KGB operatives revealed the details of Operation SIG, Hazan (2017, p. 230 ff) pointed out some methods used by the Soviets to carry out propaganda campaigns. Most of these should be familiar to the reader since they are still in use by the Russians, and early by Nazi Germany. These and other general principles of deception are outlined in Cohen (2019).

1. Distortion and Deception. Deception includes out-and-out lying as well as the highly successful techniques of "distortion," including spin. Spinning the truth, by embedding a lie within a truth, is explored below. Deception includes repeating the "big lie" (große Lüge), a lie so big that it defies logical thinking.

2. Repetition of the lie. A lie repeated enough tends to become believed. This phenomenon, the "illusory truth effect," has been well-studies and replicated (De keersmaecker et al., 2019). Former KGB chairman Yuri Andropov said, "We bave only to keep repeating our themes that the United States and Israel are fascists, Imperial-Zionist countries bankrolled by rich Jews" (Shaw, 2019). Paul and Matthews (2016) refer to this as the Russian "firehose of falsehood" propaganda model. This technique is observed clearly when the answer is always "blame the occupation" and "Israeli aggression", no matter what the question.

3. Defamation and Misdirection, such as blaming the victim. Tawil (2019a) provides a recent example. When terrorists fire rockets at Israeli civilians, the campaign blames Israel for retaliating to cease these attacks.

4. The hijacking of emotions. Deliberate misuse of sentiment. For example, see using images of crying mothers and babies discussed in Konn and Lam (2018) and Ben Zikri (2018).

One tactic to disinform is to blame all wrong on some adversary, a monstrous bogey man. For Operation SIG campaign against the Jewish State, the KGB chose the Jews as the bogeymen. Arab antisemitism was already rampant when the KGB created Operation SIG. Preexisting Muslim antisemitism provided a fertile field to plant fake stories and disinformation about Jews and Israel. Indeed, the genius of the KGB's Operation SIG was that it brought into alliance Arab adherents of Pan-Arabism, Pan-Islamism, and Nazism around what they had in common: hatred for Jews, Israel, and democracy. Shlaim (2003) notes, "Most isms ultimately lead to war, and Arab nationalism is no exception." PanArabism has as its goal to unite all Arab countries as a single Arab nation. Pan-Islamism's goal is to reunite all lands that were ever under Islamic rule into an Islamic State. Arab Nazism calls for subjugation or murder of Jews as vermin. Operation SIG brought together existing antisemitism with existing irredentist movements to advance its aim to turn world opinion against Israel.

In support of its goal, the KGB's operation created joint ventures and recruited: 
thousands of doctors, engineers, technicians, professors, and even dance instructors. All had the task of portraying the United States as an arrogant and haughty Jewish fiefdom financed by Jewish money and run by Jewish politicians, whose aim was to subordinate the entire Islamic world. (Pacepa, 2006)

Pacepa (2006) writes that "the Kremlin decided to turn the whole Islamic world against Israel and the U.S" According to Pacepa, KGB chairman Yury Andropov told him, "We needed to instill a Nazi-style hatred for the Jews throughout the Islamic world and to turn this weapon of the emotions into a terrorist bloodbath against Israel and its main supporter, the United States." Pacepa recounted that by the time he left Romania in 1978, the Soviets "bad sent some 4,000 such agents of influence into the Islamic world... In addition, they spread throughout the Islamic world an Arabic translation of the Protocols of the Elders of Zion', a tsarist Russian forgery that had been used by Hitler as the foundation for his anti-Semitic philosophy."

Around 1967, the KGB's proxy started created media (films, printed matter in various languages) to promote its new narrative of Jews as bogeymen:

1) The Jews (the Zionists) are responsible for antisemitism,

2) Zionist organizations worldwide engage in espionage,

3) Zionism is a Trojan Horse for Imperialism and Racism in the third world (Hazan, 2017, pp 151-152),

4) The Jews collaborated with the Nazis during WWII, and

5) Holocaust Inversion, that is, Israelis as Nazis (Hazan, 2017, p. 151-155).

\section{KGB's disinformation warfare techniques}

Stalin created a particular, secret tactical office for disinformation (Manning \& Romerstein, 2004). In 1954, after Stalin's death, the USSR tasked the KGB (more accurately, the First Main Directorate of the Committee for State Security - PGU KGB) with political warfare, including disinformation, propaganda, and forgery of official documents: the details remained hidden. The world learned more about the KGB's campaigns to disinform starting only in 1991 once the USSR fell through exposés written by its operators, such as in the book KGB and Soviet Disinformation: An Insider's View written by former intelligence officer specializing in disinformation for the Czech Intelligence Service Ladislav Bittman (1985). Bittman's book points out psychological warfare techniques perfected by the KGB. The book Disinformation, written by former spy chief Lt. Gen. Ion Mihai Pacepa and Prof. Ronald Rychlak (2013), exposed more revelations.

From these books, we now know the immense success of the KGB's campaigns. (Russian intelligence services are still using the techniques used by the KBG outlined in these books.) These books provide evidence of the enormous success the KGB had in creating world opposition to Israel.

\section{DISTORTION AND DECEPTION: FABRICATING HISTORY}

"History is full of ... events that seem familiar, that elicited sense of mild too deep understanding but who's true historical context is different than we imagine"

(Sloman \& Fernbach, 2018, p. 9).

Before the KGB created the PLO, and before the establishment of Israel as a nation/state of the Jews (with both Arab and Jewish citizens), the goal of the neighboring Arab nations was to absorb the land of Israel under Arab/Muslim control. The aspiration was to ethnically cleanse the region of its Jews and creating a Greater Jordan, or a Greater Syria, or expanding Egyptian and Syrian occupation of the area as part of a pan-Arabic or pan-Islamic empire (e.g., "Hamas Official Mahmoud AlZahhar," 2017).

In support of these territorial expansion strategies, in 1948 the armies of Egypt and Transjordan joined other Arab armies to invade the newly established State of Israel. Following this invasion, Egypt and Transjordan retained the lands they succeeded in conquering. Their war created two sets 
of refugees: 1) Some of the Arabs of the region who left their homes before or during the war, and 2) a larger number (almost all) of Jews ejected from their homes in Arab lands and Judea and Samaria.

Under the guidance of the KGB, the idea of the Arab refugees as a distinct people took hold. In particular, the KGB generated a storyline that nowadays is often taken as factual:

1. The PLO, from its start, expressed the will of the Arabs living the geographic region Palestine, rather than the will of Moscow to create divisions and overthrow democracy.

2. Palestine is not just the name for a geographic region, but the home for a distinct and indigenous people, the Palestinian Arabs. Its Jewish citizens are colonizers from some unidentified foreign country. (In contrast, the Jews consider their return to their homeland as self-emancipation, as witnessed in Leon Pinsker's 1882 pamphlet “Auto-Emancipation.”)

3. Israel practices apartheid in which the Arab citizens of Israel are prevented from advancing.

4. Arab poverty in the territories controlled by Arabs is due to Israel, rather than to the Arab rules Hamas and the PLO.

Let us explore these points and relate them to the historical record.

\section{THE PLO AS AN APPARATUS OF THE KGB}

According to Ion Mihai Pacepa (as cited in J. Bergman, 2016), the "Palestinian Liberation Army" was contrived by the KGB, much like the KGB devised the Bolivian National Liberation Army. It created this Arab army in the early 1960s following the failure of the troops of various Arab states to destroy Israel. Pacepa (2006) stated that the KGB drafted the Palestinian National Charter and handpicked the 422 members of the PLO council that approved it. Andropov told Pacepa, "We needed to instill a Nazi-style hatred for the Jews throughout the Islamic world, and to turn this weapon of the emotions into a terrorist bloodbath against Israel" (Pacepa, 2006). Likewise, both the Palestine National Covenant and Palestinian Constitution were drafted in Moscow (Pacepa, as cited in J. Bergman, 2016).

In understanding the real purpose of the PLO, it is useful to know that the 1964 charter, article 24, specifically demanded control of Israeli lands and expressly excluded lands already under Arab control, Judea and Samaria (written as the West Bank of the Hashemite Kingdom of Jordan) and Gaza.

Article 24: This Organization does not exercise any territorial sovereignty over the West Bank in the Hashemite Kingdom of Jordan, on the Gaza Strip or in the Himmah Area. Its activities will be on the national popular level in the liberational, organizational, political, and financial fields. (Translation by Harkabi, 1979).

Meir-Levi (2007b) and Shaw (2019) note the prowess of the KGB in establishing an anti-democratic and anti-Zionist sentiment via the Arabs. The KGB's campaign was a historic success. It started with huge expenditure on personnel by the KGB. In his review of Pacepa and Rychicak's book (2013), former Director of Central Intelligence R. James Woolsey (2013) comments: "Gen. Pacepa writes that there were more in the Soviet bloc working on dezinformatsiya than in the armed forces and defense industry!"

Yasser Arafat. While this paper focuses on the disinformation campaign, we note in passing the military element of the KGB/Arab asymmetric warfare against Israel, that is, terrorism. Pacepa (2006) notes that with KGB financing the PLO hijacked 82 planes in 1969 alone. PLO strongman Yaser Arafat (along with KGB General Aleksandr Sakharovsky) claim credit as the originator of airplane hijacking. Following Pacepa's revelations of Arafat's claim, Muammar Gaddafi and Yasser Arafat each offered US $\$ 1$ million for the assassination of Pacepa (Stan, 2013).

More recent Russian disinformation campaigns against Ukraine and the US echo the Russian playbook described below. Cain (2019) writes, "The Crimean annexation was an early masterstroke of fake news and pseudo-history...Fake news plunged parts of Ukraine into a post-truth, alternate reality. President Vladimir Putin's disinformation machine convinced his supporters that fascists and enemies lurked everywhere..."Below, the 
paper explores the KGB success in portraying Jews as fascists, fomenting hatred, and creating a fake history.

According to Pacepa (2003), the KGB singled out Yasser Arafat to help it in its campaign of disinformation. The KGB trained Arafat at "its Balashikha special-ops school east of Moscow and in the mid-1960s decided to groom him as the future PLO leader" (Pacepa, 2003). In a February 1972 discussion with KGB Chairman Yuri Andropov, Andropov told Pacepa that the KGB would mold Arafat's Marxist ideals into a rabid anti-Zionist. Pacepa (2003) wrote, "In 1969 the KGB asked Arafat to declare war on American 'imperial-Zionism'... It appealed to him [Arafat] so much, Arafat later claimed to have invented the imperial-Zionist battle cry. But in fact, 'imperial-Zionism' was a Moscow invention, a modern adaptation of the Protocols of the Elders of Zion, and long a favorite tool of Russian intelligence to foment ethnic hatred [emphasis ours]. The KGB always regarded anti-Semitism plus anti-imperialism as a rich source of anti-Americanism."

Arafat's Nazi antisemitism. Using Arafat, the KGB also built on the Nazi antisemitism advanced by Mufti al-Husseini (Meir-Levi, 2007a.) The KGB "also selected a 'personal hero' for him [Arafat] -- the Grand Mufti Haj Amin al-Husseini, the man who visited Auschwitz in the late 1930s and reproached the Germans for not having killed even more Jews" (Pacepa, 2003). See Figure 3 and Hajj Amin al-Husayni meets Hitler (1941) for more information.

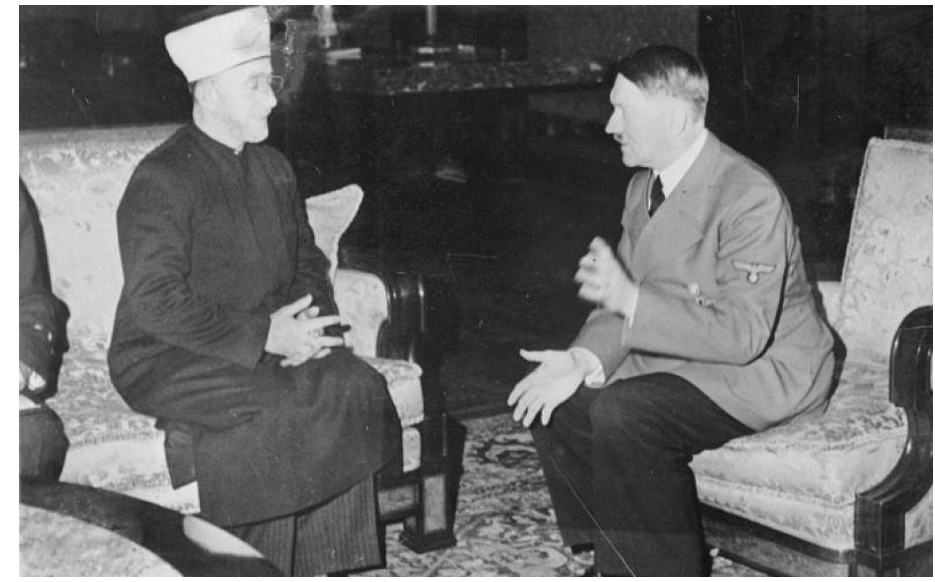

Figure 3. Hitler and al-Husseini, planning for the reunification of Syria, Iraq, and the British Mandate as a single Arab state, and the "elimination" of Jews.

(Source: "Full official record." 2015)

Dalin (2005) writes, "the PLO recruited two former Nazi instructors, Erich Altern, a leader of the Gestapo's Jewish affairs section, and Willy Berner, an S.S. officer in the Mauthausen extermination camp. Another former Nazi, Johann Schuller, was found supplying arms to the Fatah. The Belgian Jean Tireault, secretary of the neo-Nazi La Nation Européenne, also went on the Fatah payroll. Still another Belgian, the neo-Nazi Karl van der Put, recruited by the PLO. ... Arafat always revered al-Husseini" (p 131).

Mahmood Abbas. Following Arafat's death, control of the PLO passed to another KGB operative, Mahmoud Abbas. The Mitrokhin documents note that the KGB began to recruit Abbas around 1979 when he arrived in Moscow for graduate studies. While there, he wrote as his dissertation The Other Side: The Secret Relationship Between Nazism and Zionism, a conspiracy theory about the Holocaust that included accusations that the Jews helped Hitler (R. Bergman, 2016). He continues to espouse this conspiracy theory. In 2018 he said in Arabic that the while Holocaust did happen, it was caused not by antisemites but rather by the Jews. His speech added that Jews did not seek to create Israel and that Jews have no connection to the Land of Israel ("Abbas says Jews" behavior, not anti-Semitism, caused the Holocaust," 2018). 
Kleptocracy. The above evidence shows that the KGB, not the Palestinian people, choose Arafat and Abbas. Arafat used his autocracy for personal gain. During Arafat's lifetime, he diverted from $\$ 1$ billion to $\$ 3$ billion to his personal accounts (McDermott, 2003).

The same is true for Arafat's second in command and, upon Arafat's death, his successor, Abbas. "Billions of euros in European aid sent to the Palestinians may have been misspent, squandered or lost to corruption," according to a damning report by the European Court of Auditors, the Luxembourg-based watchdog (Pancevski, 2013). Dana (2015) writes that corruption by the PLO continues; as many as $81 \%$ of the Palestinians view Palestinian Authority institutions as corrupt ("Abbas says Jews' behavior," 2018). Democratically elected Abbas is now in the 15th year of his 4-year term.

(The PLO and Palestinian Authority are slightly different organizations with few differences. The Palestinian Academic Society for the Study of International Affairs' chart at https://israelbehindthenews.com/plo-pa-table/18946 compares the two intertwined organizations.)

In sum, the KGB created the PLO (see Figure 4), and at least initially, the PLO did not express the will of the Arab population under its control. In the next section, we examine techniques used to turn world opinion against the Jews and Israel and to create a new narrative.

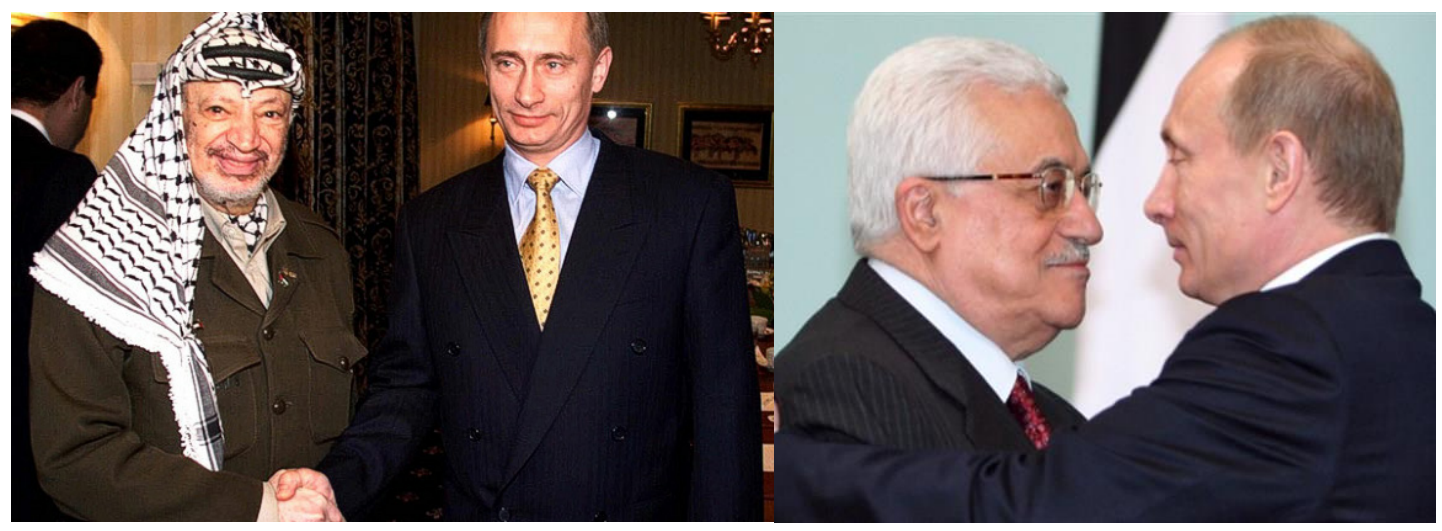

Figure 4. PLO chief Yasser Arafat and KGB Agent Vladimir Putin (Source: Weingarten, 2015) and Mahmood Abbas and President of Russia Vladimir Putin (Source: Benari, 2019)

\section{REDEFINING PALESTINE}

Part of the operation was to redefine who is a Palestinian, claiming the land belongs to only the Arabs and denying Jewish historical and religious attachment to Israel.

In 1919, after the Ottoman-Turks lost WWI, Britain and France carved up the Ottoman Empire. In 1920 (finalized in 1922), the League of Nations created the "Mandate for Palestine," which laid down the legal right of Jews to settle anywhere in western Palestine.

In 1922, the British split the geographic region known as the British Mandate for Palestine in two. The Arab Palestine territory to the west of the Jordan river was named Trans-Jordan (See Figure 5. The Palestinian Academic Society (Passia.org) shows a similar map.) 


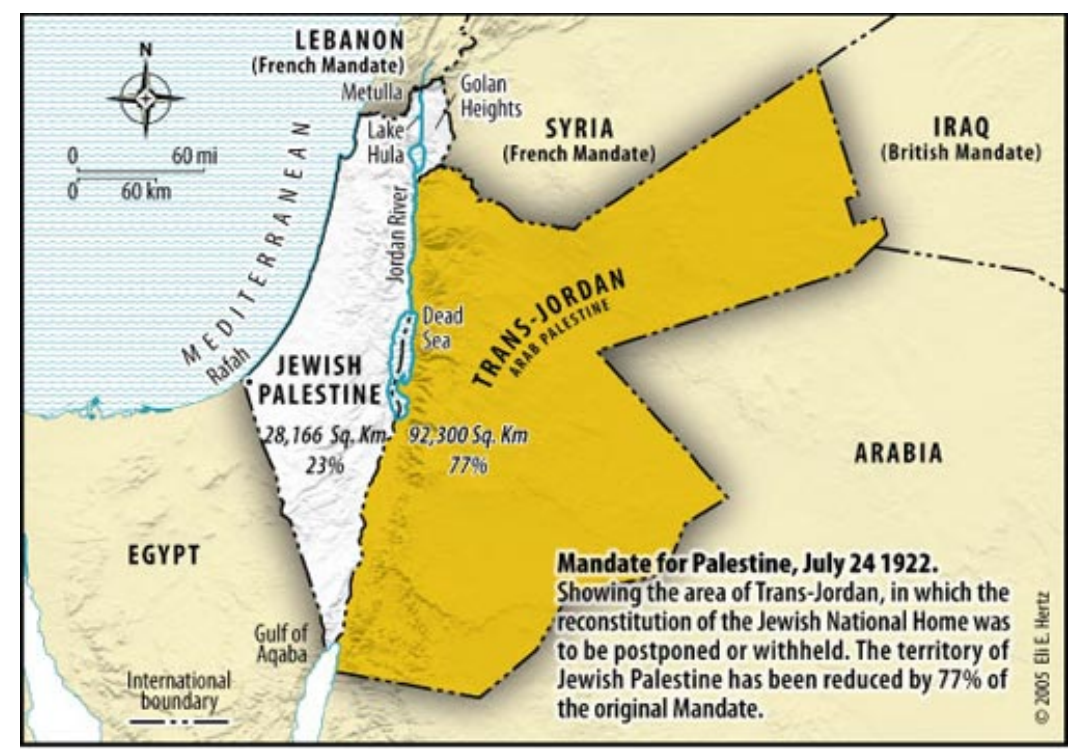

Figure 5. Mandate for Palestine after separation into two parts in 1922 (Source: Hertz, 2006)

The borders of many modern Arab countries in the region are the result of the British and French carving up the former Ottoman Empire with borders along map meridians rather than by indigenous populations, geographic logic, or sustainability. This simplistic concoction of borders served the needs of the British and French, but in doing so created artificial nationalities that never existed before: the Lebanese, Jordanians, Syrians, and Iraqis, according to Dawisha in his book "Arab Nationalism in the 20th Century: From Triumph to Despair" (2002, as cited by Shlaim, 2003, in The Guardian). Much of today's conflicts in the Middle East can be attributed to this approach. For example, the Kurdish people were split across three of these newly created political entities and thus denied their own homeland.

Palestine as a Geographic Area. In Roman times, the term Palestine referred to a geographic region of land south of Syria. Under the British Mandate, the term referred to the more limited area of what is now Jordan and Israel. A local advocate for Arab nationalism in Palestine and lawyer for the Supreme Muslim Council, Awni Abd al-Hadi, testified before the Peel Commission in 1937 that "There is no such country [as Palestine]! Palestine' is a term the Zionists invented! There is no Palestine in the Bible. Our country was for centuries part of Syria" ("Awni Abd al-Hadi", n.d.) During the 19 years that Trans-Jordan occupied the territories west of the Jordan river and until recently, no Arab state even creating a separate state for its Arab residents (Hertz, 2017).

Bassam Tawil, a Muslim Arab based in the Middle East, notes that many Palestinian officials and media outlets refer to Israel as "occupied Palestine... For them, all Jews are settlers and colonizers, and all cities inside Israel -- Tel Aviv, Haifa, Ashkelon, Ashdod, Eilat, as well as Lod, the hometown of Rina [a 17-year-old Jewish girl killed by an Arab terrorist]-- are "occupied." In the eyes of Palestinians, in fact all of Israel is "occupied" and a "settlement." (Tawil, 2019a).

That new anti-Israel narrative started by talking about the Arabs of the Palestinian region as a distinct people, the Palestinians, even though these Arabs failed to meet the commonly held criteria of peoplehood.

Arabs as the Palestinian People. Peoplehood typically is understood to be a group of people who possess distinctness in language, religion, history, culture, historical sovereignty, national literature, and such. For example, the Kurds, Armenians, Catalonians, Bangladeshis, Slovakians, Slovenes, and Jews are peoples. The uniqueness of Arab Palestinians needed to be constructed whole cloth since they lacked the criteria required for peoplehood, but this creation was and is essential to claim the land of Israel as the homeland for Arabs alone as Palestinians. "Historically, the Palestinian 'desire for 
statehood' and 'need for liberation' was invented in large part by the Soviet Union," according to Christopher Fish writing in the Stanford Review (2008). He writes, "Palestinian nationalism is, therefore, a historical fabrication born out of a communist thirst for expansion and an Arab resentment of the existence of Israel."

In the early 1900s, before Israel's establishment, the term "Palestinian" primarily referred to the local Jews and their institutions. For example, the Palestine Post newspaper (founded in 1932), books on Palestinian folk songs and folk tales, and the Palestinian Philharmonic (founded in 1936) all related to the Jewish people living there and to their institutions.

The Arabs living there identified themselves as people of Greater Syria or Transjordan. (Modern Syria leadership still aspires to control not only Lebanon but also Israel and Jordan.) While some Arab families (like the Jews) had lived the pre-British Mandate Palestine for generations, most were immigrants from other parts of the Ottoman Empire, many forcibly relocated by their Islamic Ottoman rulers, some as punishment (Blumi 2013).

Nonetheless, the current Chairman of the PLO (and President of the Palestinian Authority ) asserts without evidence that the current Arab inhabitants of the area are the descendants of the Canaanites, one of the peoples who lived in the area about 5,000 years ago ("Palestinian Authority President Abbas at Jalazone Refugee Camp," 2019). Note that in making this claim, Abbas unintentionally asserted that Arab Palestinians are not Arabs since the ancient peoples of Canaan were not Arabs. Even more damning for Abbas's assertion are genetic studies published in the American Journal of Human Genetics which show that that present-day Lebanese, not the Arabs under Abbas's control, descended from the ancient Canaanites (Haber et al., 2017).

Arab Skepticism. The KGB's creation of a new, separate identity for the Arabs living in the western portion of the British Mandate Palestine as a distinct and ancient people has been met with considerable skepticism among Arabs.

In 1937 testimony before the Peel Commission, Syrian leader Auni Bey Abdul-Hadi (aka Awni Abd al-Hadi) asserted: "There is no such country [as Palestine]. ... Palestine' is alien to us. It is the Zionists who introduced it." (Tal, 1994, p. 93).

In 1946, Prof. Philip K. Hitti, author of the book "The Arabs," testified at the Anglo-American Committee of Inquiry, "There is no such thing as Palestine in history" (as cited in Horwitz \& Grimes, 1959).

In 1956, Ahmad Shukeiri, a founder of the PLO, echoed this in his testimony before the UN Security Council in his capacity as Ambassador of the Arab League, "Such a creature as Palestine does not exist at all. This land is nothing but the southern portion of Greater Syria. It is common knowledge [emphasis mine] that Palestine is notbing but southern Syria" (Behan, 2018).

In 1977, Zahir Muhsein, executive committee member of the Palestine Liberation Organization, admitted in an interview by a Dutch newspaper (Dorsey, 1977), "The Palestinian people does not exist. The creation of the Palestinian state is only a means of continuing our struggle against the state of Israel for our Arab unity. In reality, today, there is no difference between Jordanians, Palestinians Syrians, and Lebanese. Only for political and tactical reasons do we speak today about the existence of a Palestinian people ... to oppose Zionism. ... The moment we reclaim our right to all of Palestine, we will not wait even a minute to unite Palestine and Jordan".

In 2012, Palestinian Minister Fathi Hammad said, "Brothers, half of the Palestinians are Egyptians, and the other half are Saudis. Who are the Palestinians? We have many families called Al-Masri, whose roots are Egyptian. Egyptian! They may be from Alexandria, from Cairo, from Damietta, from the North, from Aswan, from Upper Egypt. We are Egyptians. We are Arabs. We are Muslims" (Camay, Hussein, \& Stone, 2016). (Yasser Arafat was born and raised in Cairo, Egypt.)

Historian Jerold Auerbach (2019) writes in “When were the 'Palestinians' invented?",

Even Columbia history professor Rashid Khalidi, an expert on Palestinian identity, would acknowledge that before World War I "Palestine" did not exist in Arab consciousness. Zionist land development served as a 
magnet for Arabs from Middle Eastern countries who came to Palestine in search of a better life and eventually became "Palestinians."

Even the UN General Assembly Resolution in 1947 referred to the area west of the Jordan River as Judea and Samaria. A distinctive Palestinian identity did not emerge until the bumiliating Arab defeat in the SixDay War.

Creating a national identity of Palestinian Arabs as a pre-existing people required inventing a posttruth history. Nazmi Al-Ju'beh, associate professor of history and archaeology at Birzeit University, acknowledged this in 2008 when he wrote that Arab Palestinian identity was invented solely to destroy Israel. He writes, "There is no way to understand this identity apart from the conflict" (Al-Ju'beh, 2008). Khalidi (1997) writes similarly.

The oldest academic journal to claim Arab Palestinians as a people, the Journal of Palestine Studies, was created in 1972, five years after Operation SIG began. The importance of this is that, once an academic journal publishes a paper, the contents of the paper take on a reputation as credible and its papers are repeated as real by reporters, politicians, and textbook writings. This process creates "fake history" (De Baets, 2019).

\section{THE APARTHEID SLANDER}

One central and pervasive antisemitic smear accuses Israel of promoting apartheid. The impetus for writing this paper was an email from a colleague in the UK stating, "I cannot in conscience has (sic) anything at all to do with this apartheid state" referring to Israel. Reed Anfinson (2018) points out that propaganda is successful because the truth cannot compete with lies on social media. "Faced with wildly conflicting versions of reality, people selected the one that suited them" (Pomerantsev, 2019). Irrational beliefs like this enable people otherwise of goodwill to endorse antisemitism.

Professor Alan Johnson (n.d.) explores this smear in great depth. His research includes the following quote from a journalist who is an Arab citizen of Israel, Khaled Abu Toameh: If Israel were an apartheid state, I, for example, would not be allowed to work. for a Jewish newspaper or live in a Jewish neighbourbood or own a bome. The real apartheid is in Lebanon, where there is a law that bans Palestinians from working in over 50 professions. Can you imagine if the Knesset [Israeli Parliament] passed a law banning Arabs from working even in one profession? The law of Israel does not distinguish between a Jew and an Arab.

PLO, Jordan, Gaza practice Apartheid. Contrast this with the declaration by the ruler of the Palestinian Arabs, Mahmoud Abbas, who wrote that the Palestinian Authority "will never allow a single Israeli [Jew] to live among us" (Wallace, 2012, p. 40). The same is true of the Arab Palestinian State of Jordan.

Israel has citizens of all religions and colors, unlike many Arab nations, yet these Arab countries are not mentioned, much less condemned. Indeed, the only area in geographic Palestine (Jordan, Israel, Gaza, and the territories) where Arabs and Jews can both live as citizens is in Israel.

Claiming that Israel practices apartheid makes no rational sense. This paper suggests that the KGB planted the seed for such an antisemitic propaganda campaign in Operation SIG. That seed of antisemitism has now blossomed, flowered, and spread its antisemitic seeds throughout the world.

\section{BLAMING ISRAEL FOR POVERTY IN AREAS UNDER ARAB CONTROL}

Poverty is a real problem throughout the world. Economists have precise definitions of poverty that allows for comparisons across time and place. In simple terms, the poverty line is the minimum level of income deemed adequate in a particular country. The poverty rate is the percentage of people with income below the poverty line.

In Israel, the poverty rate among Israeli Arab families is $47 \%$, a bit more than among ultraorthodox Jews at 43\% (Einhorn, 2018). 
Areas under Arab control. The Palestine-Israel Journal of Politics, Economics, and Culture, citing World Bank Group data (2000), shows the 1998 poverty rate among the Arabs living the West Bank at 14.5\% and those living in Gaza at 33\% ("Poverty in the West Bank and Gaza," 2000). This poverty, while much lower than in Israel, exists even though "the Palestinian National Authority in the West Bank and Gaza Strip receives one of the highest levels of aid in the world" ("International aid to Palestinians," n.d.). The money provided by the international community to fight poverty in areas controlled by Arabs is not reaching the poor.

According to the UN, under Hamas' control of Gaza, the number in poverty jumped to $53 \%$ (United Nations Office for Coordination of Humanitarian Affairs, 2018).

In Jordan. Most Arabs who identify as Palestinian live in the portion of Palestine east of the Jordan river; that is, most Arab Palestinians live in the Kingdom of Jordan, where they constitute the majority of the country's population. According to the Jordan Times, a third of the population (33\%) lives below the poverty line (Obeidat, 2014).

In short, poverty is a real problem for Israelis (Jews and Arabs) and Palestinian Arabs. It jumped in Gaza under Hamas. The increase in poverty in Gaza may be due to corruption in the UN agency that was supposed to support Arabs in Gaza and the West Bank. This topic may be separate from Operation SIG but relates directly to disinformation, propaganda, and antisemitism, as shown below.

Corruption of UNRWA: Financial. The UN created the United Nations Relief and Works Agency (UNRWA) to solve the problem of Arab refugees of the Arab war against Israel. It failed. Since its inception, UNRWA expanded its mission, size, influence, and wealth.

What is more, the World Bank report notes financial corruption with UNRWA, with its squandering and misspending the enormous amounts of humanitarian assistance that were donated to aid the population. Asaf Romirowsky and Alex Joffe's $(2011,2019)$ investigations into UNRWA revealed the means and depth of its fraud. Many donor countries have suspended their funding. UNRWA financial corruption was on such a large scale that not only the West but even the PLO has called for a probe ("PLO calls for UN to accelerate UNRWA corruption probe," 2019).

Providing Incentives to Commit Terrorism: Pay to Slay. The Palestinian Authority (PA) is proud to provide incentives to commit terrorism and even cut its support for medical care to provide this funding. The PA admitted to spending $\$ 134$ million in salary payments to terrorists. The Palestinian Authority has paid female terrorist Ahlam Tamimi and six others for murdering 15 people, seven of them children, and wounding close to 130 others $\$ 910,823$ in salary so far (Jaffe-Hoffman, 2019b). Tamimi now lives free in Jordan.

US special envoy to the Middle East Jason Greenblatt is quoted as saying the Palestinian Authority pays more than USD 13,000,000 monthly to terrorists. (Jaffe-Hoffman, 2019a).

Mahmoud Abbas has repeatedly stated that he has no intention of eliminating the incentives to violence, understanding that this comes at the expense of welfare of Palestinians who prefer to live normal lives and not having Arabs killing Jews (“Abbas keeps on defying U.S," 2018). Indeed, Abbas has doubled payment to the terrorist who murdered three Israeli teenagers. ("PA doubles pay-to-slay salary," 2019). Abbas is also quoted as saying that terrorists (whom he calls "martyrs") are the most sacred thing we have. ("Palestinian Authority President Abbas at Jalazone Refugee Camp," 2019). In the same speech, Abbas vowed to destroy the homes of all Jews.

The point is that the Arab Palestinian leadership diverted funds provided by the international community to improve the lives of Arab Palestinians to promote terrorism. 


\title{
LYING AND REPETITION OF THE LIE
}

\author{
"The ability to reframe any point quickly, turn eyes toward a specific topic, \\ and even spout false information with impunity... \\ allows governments to create the conditions designed expressly \\ to keep the rest of us in the dark" (Nguyen, 2019).
}

The essence of disinformation is the willingness to lie and get others to spread the lie.

The above section dealt with the fake narrative that was devised by the KGB. The paper now explores additional tactics employed in Operation SIG and by the PLO: creating and disseminating lies, using "useful idiots" and "willing collaborators" to repeat your lie, and infiltrating organizations to be seen as trustworthy, that is, intersectionality.

David Meir-Levi (2007b) writes: “Arafat was particularly struck by Ho Chi Minh's success in mobilizing leftwing sympathizers in Europe and the United States, where activists on American campuses, enthusiastically following the [propaganda] line of North Vietnamese operatives, had succeeded in reframing the Vietnam war from a Communist assault on the south to a struggle for national liberation. Ho's chief strategist, General Giap, made it clear to Arafat and his lieutenants that in order to succeed, they too needed to redefine the terms of their struggle. Giap's counsel was simple but profound: the PLO needed to work in a way that concealed its real goals, permitted strategic deception, and gave the appearance of moderation: [emphasis mine] 'Stop talking about annibilating Israel and instead turn your terror war into a struggle for human rights. Then you will have the American people eating out of your hand."”

Fish (2008) quotes advice from Algerian Minister of Information Muhammed Yazid to Yasser Arafat: "wipe out the argument that Israel is a small state whose existence is threatened by the Arab States, or the reduction of the Palestinian problem to a question of refugees; instead present the Palestinian struggle as one for liberation like the others. Wipe out the impression that in the struggle between the Palestinians and Zionists, the Zionist is the underdog. Now it is the Arab who is oppressed and victimized in his existence because he is not only facing the Zionists but also world imperialism."

The KGB and other communist leaders continued to influence, if not control, the PLO. Pacepa (2003) tells that "in March 1978, I secretly brought Arafat to Bucharest for final instructions on how to behave in Washington." He writes that Romanian dictator Nicolae Ceausescu instructed Arafat to pretend that he would break with terrorism and recognize Israel and say this over and over, a fake offering of the olive branch.

Most Westerners mistakenly believe that when the PLO and Hamas refer to "occupied lands" they mean the territories that Arab nations lost to Israel during their 1967 war. However, it is clear from the various Palestinian Arab documents and speeches that what the Palestinian Arab leadership refers to as "occupied land" is the entirety of Israel, that is, the destruction of Israel.

Deceiving the West works as a tactic in changing public opinion, giving the illusion that Arafat was willing to become a statesman, offering peace with the Jewish State in exchange for Judaea, Samaria, and Gaza to create a homeland for the Arab Palestinian. Israel, indeed, handed control of territory to the PLO in return for the promise of peace. Two years after Israel signed and complied with the Oslo accords, it became clear that Arafat's commitment was a tactical lie. Arab terrorism against Jews increased under Palestinian semi-autonomy. The number of Israelis murdered by Arab terrorists increased by 73\%. Bedein (2019) writes, "People do not generally know that the PA [Palestinian Authority], the PLO administrative arm, has enacted an unprecedented ordinance to provide an automatic gratuity - for life - for anyone who murders a Jew." (This topic is explored above under pay-to-slay.)

In a 1994 speech in Johannesburg, Arafat acknowledged that he deliberately misled the world and did so rationalizing an interpretation of Islamic law that permits lying (Arafat, 1994). Was Arafat's use of lying about seeking peace permissible within Islam? Professor Joel Hayward, Professor of Strategic Thought at the National Defense College of the United Arab Emirates, researched this topic in his 
book War is Deceit (2017). Hayward found that the approach of lying to advance an Islamic cause is in accord with Islamic law.

Lying is effective, particularly when the lie is repeated. Spinny (2017) notes that societal collective memories may produce false memories from repeated lies.

"Despite the fact that footage of a recent terror attack clearly shows two Palestinians ambushing Israeli officers in a stabbing attack that left one officer seriously wounded, the Palestinian Authority broadcast outlandish lies about the incident." write Professor Itamar Marcus and Maurice Hirsch (2019).

Even outrageous lying is effective not only because some who hear it will believe it, but because useful idiots, willing collaborators, journalists, and anti-Israel activists echo the lies to each other and the public. Who are these useful idiots and willing collaborators?

\section{GETTING OTHERS TO SPREAD LIES: USEFUL IDIOTS AND WILLING COLLABORATORS, JOURNALISTS AND ACTIVISTS}

Lying is effective for deception; getting others to spread the lie serves as a force multiplier. Another tactic of deception employed by the KGB to weaken or destroy Israel is by exploiting the "Useful Idiot." This term, attributed to Vladimir Lenin, refers to recruiting a useful pawn, one who is not aware of being manipulated, to disseminate one's propaganda. The device works well with young, impressionable youth looking for a cause to support. Rachel Corrie, for example, died standing in front of a bulldozer clearing out the tunnels used by terrorists to attack Israeli civilians from Gaza. Her death became a huge propaganda success. These and other elements of cognitive hacking (ways to manipulate perception) are explored below and in Cybenko, Giani, and Thompson (2002).

Reporters, Planted Stories, and controlling the vocabulary. A report issued by the research institute Data and Society (Donovan \& Friedberg, 2019) identifies the tools and tactics the PLO and others use to employ well-meaning journalists and others to disseminate misleading and outright false information.

Planting Stories. One technique to influence reporters involves planting a fake story that looks like legitimate news in some friendly outlet (such as RT or Aljazeera). "Then they (the Russians) use fake accounts to amplify the story — repeatedly tweeting it, making it appear like it is being shared by real people, making it 'trend' - until someone like a journalist, or maybe a politician, shares it and it goes into the mainstream" (David Halevy, a Jerusalem-based correspondent for Time Magazine, as cited in O'Sullivan, 2019).

Staging Events for the Naïve Reporter. Other times, reporters needing a news report to file, collaborate with their Arab handlers who arrange for an event. For example, Tuvia Tenenbom (2015a) posed in the territories as a naïve German reporter and discovered how the Palestinian Authority (PA) organizes fake news events for naïve reporters who show up needing to file a story. His PA handler drove him to a location and asked him to document for his newspaper, an event they staged for him.

NGOs as Witting Collaborators. Another technique Tenenbom (2015b) discovered involves locating those already convinced that Jews are evil. He writes that NGOs use their money to "implant hate in the heart of the Palestinian against the Jew... They (the NGOs) believe to the core of their being that the Jews are bad". These NGOs bring in naïve European youth to "to catch the Jew" (the title of his book). Gerstenfeld (2015) provides details on how NGOs provide economic and political support to collaborate with those who produce fake anti-Israel propaganda. At other times, the tactic is to create an event. Recently Hamas massed thousands of civilians intermixed with their armed soldiers to cross into Israel. They use the resultant deaths in their propaganda war, taking the spotlight off Hamas's failure to build an economy for those it governs (for example, see., Morris \& Balousha, 2018). NGO Monitor publishes descriptions of the funding and activities of NGOs in the context of the Arab-Israeli conflict. 
Academic Useful Idiots. Antisemitic teaching is now prevalent in ethnic studies departments. Recently the State of California called upon its education department to create a model curriculum for the teaching ethnic studies in elementary and secondary schools, with the hopes that getting to know more about others will reduce animosity and violence against them. Instead, the ethnic studies committee that originally was designated to create the model hijacked it and offered the state a curriculum that was the State deemed to be antisemitic political indoctrination, promoting hatred and inciting harm against Jews and Israel. Following a public outcry, the State Board of Education rejected the draft (California State Board of Education, 2019).

Reciprocation. Robert Cialdini (2007) notes that an effective way to influence and persuade people is by reciprocation (I will march in your parade if you march in mine). We seek out informational sources from like-minded people. In the US, antisemites joined special interest groups, even ones with contrary viewpoints, to sway those groups toward antisemitism (Engel, 2019). Lipstadt (2019, p. 195) writes, "Using a language of shared oppression, progressive groups have made Israel part of the matrix of their concerns."

Homophilous Channels. We tend to believe and repeat to others what we hear from friends and people we think are like us in some way, that is our communities, yet "[c] ommunities can have an insidious effect on what people believe and consequently on their decisions and actions" (Sloman \& Fernbach, 2018, p 260). A result can be trusting untrustworthy narratives. It is the "credibility" element that will present the greatest obstacle to the purveyors of fake news. This explains why techniques such as repetition and the use of homophilous channels must be employed. While there is little cost to accepting the false narrative, Gill (2019) points out that "communicating outright rejection of a fake news story could potentially result in exclusion (e.g., we might be 'unfriended' on Facebook) from a homophilous group that is otherwise unanimous in its acceptance" (p. 130)

\section{BUILDING ON NAZI ANTISEMITISM}

Above the paper acknowledges the genius of Operation SIG to bring together pan-Arabists, pan-Islamist with the Arab followers of Nazism. The paper now explores Operation SIG's active measures to re-use existing Nazi and Russian antisemitic propaganda, particularly the image of Jews as subhuman vermin.

Even before the KGB created the PLO, Nazism found active support through the Arab world. This fact belies the mistaken beliefs that the Arab/Israeli wars are the source of Arab terrorism.

Russian antisemitism predates Nazism. The Czarist's fabricated antisemitic tome "The Protocols of the Elders of Zion" spread to feed the antisemitism in Nazi Germany and via the KGB to the Arabs. Moslems were familiar with Quranic verses antagonist to Jews. Operation SIG blew upon these embers of Muslim antisemitism. General Ion Mihai Pacepa (2006) wrote that, in addition to spreading an Arabic translation of "The Protocols of the Elders of Zion," "We also disseminated a KGB-fabricated "documentary" paper in Arabic alleging that Israel and its main supporter, the United States, were Zionist countries dedicated to converting the Islamic world into a Jewish colony."

\section{SUMMARY: KGB TECHNIQUES USED AGAINST ISRAEL}

The start of the paper listed some techniques noted by Hazan (2017, p. 230ff) used over 40 years ago in the then Soviet campaign against Israeli democracy. We now return to that list with some annotations and a few additions in the following summary listing of the disinformation campaign's techniques.

1) Deception. Deception includes out-and-out lying as well as the more effective "distortion," including spin.

2) Repetition. Adolph Hitler wrote that to convince the masses, keep repeating the lie. In the context of the Middle East, this technique is observed as, no matter what the question, the 
answerers keep repeating "blame the occupation" and "Israeli aggression." When a mentally unbalanced Christian tourist to Israel set a fire in the Al Alsa Mosque in 1969, the Soviets called it a criminal act but blamed Israel. (The mosque was then and continues to be under the authority of the Muslim Waqf.)

3) Blame the victim. When Arab terrorists murder Jewish athletes, airline passengers, Leon Klinghoffer (the invalid murdered as part of the Achille Lauro hijacking), and French shopkeepers, they blame the Jews. More recently, when terrorists fire rockets at Israeli civilians, the campaign blames Israel for retaliating. See also Tawil (2019b.)

4) Deliberate misuse of sentiment. As early as 40 years ago, the KGB used themes of brutalized children to invoke anti-Israel sentiment. Even the death of Anne Frank, a Jewish victim of Nazi terror, is exploited to turn world opinion against Israel.

In addition to these methods mentioned by Hazan, this paper points out other techniques, including the following:

5) Employing tribalism of homophilous groups by infiltrating organizations that have their own agenda to inject an antisemitic agenda and creating creates a spiral of silence.

6) Deploying "useful idiots" (well-meaning but ignorant people), for example, to participate in anti-Israeli days on campuses.

Likewise, techniques noted in Langer (1999) can be seen in how Arafat, Abbas, and their colleagues have dealt with Israel and in more current disinformation campaigns throughout the world:

- Telling Big Lies. Keep repeating a falsehood and treating as if it were true and self-evident

- Deflecting. Never accepting blame; for example, when Rashida Tlaib refused to go to Israel to see her grandmother after receiving a visa from Israel to do so, she blamed Israel for her refusal.

- Maintaining a constant barrage of propaganda, so the public has no opportunity to reflect and review the truth of the assertions.

- Distracting. Never admit a fault or wrong; instead, change the topic to distract attention.

- Polarization. Never concede that there may be some good in the opposition; characterize Israelis as the new Nazis.

- Employing extremism. Never leave room for alternatives or compromise; since 1967, seven times Israel has offered peace deals that were rejected by the Arabs.

\section{CONCLUDING REMARKS}

The KGB led propaganda mechanisms spun the narrative of the Arabs as an indigenous population whose human rights have been violated by Israel. Over the past 50 years, the operation has damaged the lives of ordinary Arab Palestinians and Israeli Palestinians, both Arab and Jew. It has taken on a life of its own from its humbler start of using local Arabs as unwitting pawns in the KGB war against democracies. Moscow established Operation SIG and similar KGB operations to counter the move toward democracy around the world and to turn opinion against Russia's chief enemy, the US. The side effect of the operation is now evident:

1) It has poisoned generations of Arabs (and others) into thinking that Jews are evil. Currently, over a half-billion Arabs and Iranians reside in nations in some state of war against Israel; The population of Israel includes fewer than 7 million Jews plus about 2 million Arab and other citizens. 
2) Seventy years of Arab and Muslim hostility has, in turn, lessened the Israeli sympathy for the Arab's aspirations to establish a home in the Jordan valley. Likewise, the Kingdom of Jordan no longer aspires for the return of Arab Palestinians from the west of the River Jordan.

3) Externally, it has poisoned the minds of those teaching children and young adults. Even the US's Public Broadcasting System (PBS) has fallen prey to bogus news reports issued by Hamas and the PLO (Hollander, 2019).

This paper has focused on Operation SIG, the Moscow led campaign to overthrow democracy in Israel. Nowadays, Russia (as well as other nations opposed to democracy) continue their secret operation, exploiting social media with disinformation (Nahzi, 2019). Those who favor democracy are awakening to how Moscow exploits public opinion and starting to develop ways to counter disinformation.

Facts and Happiness. The real victim of disinformation campaigns is the truth when facts no longer matter. One persistent myth is that Einstein flunked math in school. There is a myth that the Palestinian Arabs living under PLO and Hamas rule are unhappy (and of course, Israel is blamed). It makes some people feel good to believe and teach these myths. PLO disinformation campaigns have convinced generations that the Arabs of Palestine are despondent.

However, the truth does matter. A recent international study found that those Arabs living the "Palestinian Territories" ranked about as high as the Arabs (Palestinians and Bedouins) living across the river in Jordan and that all these groups are happier than the Arabs living in Egypt, Iraq, Syria, and Yemen (as well as those living in Iran) (Helliwell, Layard, \& Sachs, 2019).

The KGB's Operation SIG is perhaps the greatest triumph of disinformation even to see the light of day, but it has taken many decades for the world to learn of this operation's success. Let us hope that this paper makes all researchers skeptical when confronted with disinformation.

\section{REFERENCES}

Abbas keeps on defying U.S., says PA will fund "Pay to Slay" program until last penny. (2018, July 25). The Tower. Retrieved from http://www.thetower.org/5488-abbas-keeps-on-defying-u-s-says-pa-will-fund-payto-slay-program-until-its-last-penny/

Abbas says Jews' behavior, not anti-Semitism, caused the Holocaust. (2018, May 1). Times of Israel. Retrieved from https://www.timesofisrael.com/abbas-says-jews-behavior-not-anti-semitism-caused-the-holocaust/

Al-Ju’beh, N. (2008.) Palestinian identity and cultural heritage. In R. Heacock (Ed.), Temps et espaces en Palestine: Flux et résistances identitaires (Of times and spaces in Palestine: The flows and resistances of identity), pp. 205-231. Presses de l'Ifpo. Retrieved from https://books.openedition.org/ifpo/491?lang=en

Anfinson, R. (2018, March 21). Truth can't compete with lies on social media. Swift County Monitor-News. Retrieved from http://www.swiftcountymonitor.com/articles/2018/03/21/truth-cant-compete-lies$\underline{\text { social-media }}$

Arafat, Y. (1994, May 10) Arafat: Oslo Accords are like Mubammad's temporary peace agreement [Video file]. Retrieved from https://www.youtube.com/watch?v $=37 \mathrm{xnaqF}-6 \mathrm{~B} 4$

Auerbach, J. (2019, February 18) When were 'Palestinians' invented? United with Israel. https://unitedwithisrael.org/the-invention-of-palestinians/

Awni Abd al-Hadi. (n.d.). In Wikipedia. Retrieved from https://en.wikipedia.org/wiki/Awni Abd al-Hadi

Bedein, D. (2019, May 3). Give feedback to the Rabbis of Schules who welcome the PLO. Israel Resource Review. https://israelbehindthenews.com/give-feedback-to-the-rabbis-of-schules-who-welcome-the-plo/18516/

Behan, D. (2018, May 23). Marc Lamont Hill's '7 myths' are not myths at all. [Blog post]. Retrieved from https://blogs.timesofisrael.com/marc-lamont-hills-7-myths-are-not-myths-at-all/ 
Ben Zikri, A. (2018, June 21). Hamas paid Gaza family $\$ 2,200$ to blame Israel for baby's death, indictment says. Haaretz. Retrieved from https://www.haaretz.com/israel-news/hamas-paid-gaza-family-to-claim-babydied-by-tear-gas-istael-says-1.6197759

Benari, E. (2019, December 27). Putin to visit Bethlehem. Arutz Sheva. Retrieved from http://www.israelnationalnews.com/News/News.aspx/273743

Bergman, J. (2016). The Soviet-Palestinian lie. The Gatestone Institute. Retrieved from https://www.gatestoneinstitute.org/9090/soviet-union-palestinians

Bergman, R. (2016, November 4). The KGB's Middle East files: Palestinians in the service of Mother Russia. Middle East Transparent. Retrieved from https://middleeasttransparent.com/en/the-kgbs-middle-east-filespalestinians-in-the-service-of-mother-russia/

Bisen, A. (2019, April 24). Disinformation is drowning democracy. Foreign Policy. Retrieved from https://foreignpolicy.com/2019/04/24/disinformation-is-drowning-democracy/

Bittman, L. (1985). The KGB and Soviet disinformation: An insider's view. Washington, D.C.: Pergamon-Brassey's. Retrieved from https://archive.org/details/sovietdisinformation2

Blumi, I. (2013). Ottoman refugees, 1878-1939: Migration in a post-imperial world. Bloomsbury. Retrieved from https://books.google.com/books?id=nTKaAAAAQBAJ

Bradshaw, S., \& Howard, P. N. (2019). The global disinformation order: 2019 global inventory of organised social media manipulation. Working Paper 2019.3. The Computational Propaganda Project, Oxford University. Retrieved from https://comprop.oii.ox.ac.uk/research/cybertroops2019

Cain, G. (2019, March 29). Ukraine's war on Russian disinformation is a lesson for America. The New Republic. Retrieved from https://newrepublic.com/article/153415/ukraines-war-russian-disinformation-lessonamerica

Calabresi, M. (2017). Hacking democracy: Inside Russia’s social media war on America. Time, 189(20), 30-35.

California State Board of Education. (2019). State Board of Education President Darling-Hammond, Vice President Straus and Member Ortiz-Licon issue joint statement on draft Ethnic Studies Model Curriculum. Retrieved from https://www.cde.ca.gov/be/pn/nr/yr19sberel01.asp

Camay, R., Hussein, S., \& Stone, D. (2016). The Arab-Israeli conflict, differing narratives. Booktango. Retrieved from https://books.google.com/books?id=hEA2DQAAQBAJ

Casad, B. J. (n.d.). Confirmatory bias. Encylopaedia Britannica. Retrieved from https://www.britannica.com/science/confirmation-bias

Center for Media, Data and Society. (n.d.). The business of misinformation. Central European University. Retrieved from https://cmds.ceu.edu/business-misinformation

Cialdini, R. B. (2007). Influence: The psychology of persuasion. New York: Collins.

Clarke, R. A., \& Knake, R. K. (2010). Cyber war. Tantor Media. Retrieved from http://indianstrategicknowledgeonline.com/web/Cyber $\% 20 \mathrm{War} \% 20-$ $\% 20 \mathrm{The}^{2} \% 20 \mathrm{Next} \% 20$ Threat $\% 20$ to $\% 20$ National $\% 20$ Security $\% 20$ and $\% 20$ What $\% 20$ to $\% 20$ Do $\% 20$ About $\% 20 \mathrm{It} \% 20$ (Richard $\% 20 \mathrm{~A} \% 20$ Clarke) $\% 20(2010)$.pdf

Cohen, E. (2019). Deception: Types, principles, and tactics. Informing Science: The International Journal of an Emerging Transdiscipline, 137-156. https://doi.org/10.28945/4487

Collins, L. (2012). Bullspotting: Finding facts in the age of misinformation. Prometheus Books.

Cybenko, G., Giani, A., \& Thompson, P. (2002). Cognitive hacking: A battle for the mind. Computer, 35(8), 5056. https://doi.org/10.1109/mc.2002.1023788

Dalin, D. G. (2005 August). Hitler's Mufti. First Things. Retrieved from https://www.firstthings.com/article/2005/08/hitlers-mufti 
Dana, T. (2015). Corruption in Palestine: A self-enforcing system. Al-Shabaka: The Palestinian Policy Network. Available online at: https://al-shabaka.org/briefs/corruption-in-palestine and at https://core.ac.uk/download/pdf/86433609.pdf

De Baets, A. (2019, May 4). Fake news about the past is a crime against history. University World News. Retrieved from https:/ /www.universityworldnews.com/post.php?story $=20190429100401197$

De keersmaecker, J., Dunning, D. A., Pennycook, G., Rand, D. G., Sanchez, C., Unkelbach, C., \& Roets, A. (2019, April 3). Investigating the robustness of the illusory truth effect across individual differences in cognitive ability, need for cognitive closure, and cognitive style. Psy ArXiv Preprints. https://doi.org/10.31234/osf.io/n7bze

Donovan, J., \& Friedberg, B. (2019). Source hacking: Media manipulation in practice. Data \& Society. Retrieved from https://datasociety.net/wp-content/uploads/2019/09/DataSociety Source_Hacking.pdf

Dorell, O. (2017, Sept 7). Alleged Russian political meddling documented in 27 countries since 2004. US A Today. Retrieved from https://www.usatoday.com/story/news/world/2017/09/07/alleged-russianpolitical-meddling-documented-27-countries-since-2004/619056001/

Dorsey, J. (1977, March 31). Wij zijn alleen Palestijn om politieke reden [We are only Palestinian for political reasons]. Trouw. Retrieved from https://en.wikiquote.org/wiki/Zuheir_Mohsen

Einhorn, A. (2018, December 31). 21.2\% of Israeli population lives below the poverty line - New report. The Jerusalem Post. Retrieved from https://www.jpost.com/Israel-News/212-percent-of-Israeli-populationlives-below-the-poverty-line-new-report- 575883

Ellick, A. B., \& Westbrook, A. (2018, Nov. 12). Operation Infektion - Russian disinformation: From cold war to Kanye. New York Times. https://www.nytimes.com/2018/11/12/opinion/russia-meddlingdisinformation-fake-news-elections.html

Engel, R. (2019, April 14). How Russian trolls weaponized social media. MSNBC On Assignment. Retrieved from https://www.msnbc.com/on-assignment/watch/how-russian-trolls-weaponized-social-media1496728643983

Fish, C. (2008) The deception of Palestinian nationalism. The Stanford Review. https://stanfordreview.org/deception-palestinian-nationalism/

Full official record: What the mufti said to Hitler. (2015, October 21). The Times of Israel. Retrieved from https://www.timesofisrael.com/full-official-record-what-the-mufti-said-to-hitler/

Galeotti, M. (2017, September 1). Controlling chaos: How Russia manages its political war in Europe. European Council on Foreign Relations. Retrieved from https://www.ecfr.eu/page/-/ECFR228 - CONTROLLING_CHAOS1.pdf

Gerstenfeld, M. (2015). The war of a million cuts: The struggle against the delegitimization of Israel and the Jews, and the growth of New Anti-Semitism. Jerusalem Center for Public Affairs.

Gill, T. G. (2019). Fake news and informing science. Informing Science: The International Journal of an Emerging Transdiscipline, 22, 115-136 https://doi.org/10.28945/4265

Goble, P. (2019, August 16). "Fake news" part of Moscow's modus operandi since 1923. The Ukrainian Weekly. Retrieved from http://www.ukrweekly.com/uwwp/fake-news-part-of-moscows-modus-operandi-since$1923 /$

Golitsyn, A. (1984). New lies for old: The Communist strategy of deception and disinformation. Dodd, Mead \& Company

Gordis, D. (2019). We stand divided. New York: HarperCollins.

Gricius, G. (2019, May 11). How Russia's disinformation campaigns are succeeding in Europe. Global Security Review. Retrieved from https://globalsecurityreview.com/russia-disinformation-campaigns-succeedingeurope/

Gross, T. (2018, November 15). Inside the Russian disinformation playbook: Exploit tension, sow chaos. Fresh Air. https://www.npr.org/2018/11/15/668209008/inside-the-russian-disinformation-playbook-exploittension-sow-chaos 
Haber, M., Doumet-Serhal, C., Scheib, C., Xue, Y., Danecek, P., Mezzavilla, M., ... \& Matisoo-Smith, E. (2017). Continuity and admixture in the last five millennia of Levantine history from ancient Canaanite and present-day Lebanese genome sequences. The American Journal of Human Genetics, 101(2), 274-282. https://doi.org/10.1101/142448

Hajj Amin al-Husayni meets Hitler. (1941). [Motion picture] Holocaust Encyclopedia. Retrieved from https://encyclopedia.ushmm.org/content/en/film/hajj-amin-al-husayni-meets-hitler

Hamas Official Mahmoud Al-Zahhar: The Quran tells us to drive the Jews out of Palestine in its entirety. (2017, March 7). Speech translated by Middle East Media Research Institute. https://www.memri.org/tv/hamas-official-mahmoud-al-zahhar-quran-tells-us-drive-jews-out-palestine-itsentirety/transcript

Harkabi, Y. (1979). The Palestinian Covenant and its meaning. London: Vallentine, Mitchell and Co.

Hayward, J. (2017). War is deceit. Royal Islamic Strategic Studies Centre. Amman, Jordan. Available at http://rissc.jo/books/en/War\%20is\%20Deceit\%20e-book.pdf

Hazan, B. A. (2017). Soviet propaganda: A case study of the Middle East conflict. Jerusalem: Keter Publishing House, Israel University Press. (Original work published in 1976)

Helliwell, J., Layard, R., \& Sachs, J. (Eds.). (2019). World Happiness Report 2019. New York: Sustainable Development Solutions Network. Retrieved from https://worldhappiness.report/ed/2019/

Hertz, E. (2006). "Mandate for Palestine:" The legal aspects of Jewish Rights. Myths and Facts. Retrieved from http://www.mythsandfacts.org/conflict/mandate for palestine/mandate for palestine.htm

Hertz, E. (2017, March 16). There has never been a sovereign Arab state in Palestine. Myths and Facts. http://www.mythsandfacts.org/article view.asp?articleID $=311$

Holiday, R. (2013). Trust me, I'm lying: Confessions of a media manipulator. Penguin.

Hollander, R. (2019). PBS newshour propaganda piece attacks Israel with bogus exploding bullets charge. Committee for Accuracy in Middle East Reporting and Analysis. Retrieved from https://www.camera.org/article/pbsnewshour-propaganda-piece-attacks-israel-with-bogus-exploding-bullets-charge/

Horwitz, R. H., \& Grimes, A. P. (1959). Modern political ideologies. Oxford University Press.

International aid to Palestinians. (n.d.). In Wikipedia. Retrieved from https://en.wikipedia.org/wiki/International aid to Palestinians

Jaffe-Hoffman, M. (2019a, July 11). PA doubles pay-for-slay salary to murderer of 3 Israeli teenagers. The Jerusalem Post. Retrieved from https://www.jpost.com/Arab-Israeli-Conflict/PA-ups-pay-for-slay-salary-to-murderer-of-3-Israeli-teenagers-in-2014-595302

Jaffe-Hoffman, M. (2019b, August 19). Sbarro terrorists have received $\$ 910,823$ in pay-for-slay funds in 18 years. The Jerusalem Post. Retrieved from https://www.jpost.com/Arab-Israeli-Conflict/18-years-afterSbarro-suicide-attack-PA-has-paid-910823-to-the-culprits-598106

Johnson, A. (n.d.). The apartheid smear. British Israel Communications \& Research Centre. http://www.bicom.org.uk/wp-content/uploads/2014/02/BICOM Apartheid-Smear FINAL.pdf

Jowett, G., \& O'Donnell, V. (2005). What is propaganda, and how does it differ from persuasion? In G. Jowett \& V. O'Donnell, Propaganda \& Persuasion (pp. 1-46). Sage Publications.

Khalidi, R. (1997). Palestinian identity: The construction of modern national consciousness. New York: Columbia University Press. Retrieved from http://communication.ucsd.edu/fields/comm158/RashidKhalidi.pdf

Konn, D., \& Lam, P. F. (2018, May 19). Why Hamas is sending children into Gaza conflict zones. South Cbina Morning Post. Retrieved from https://www.scmp.com/comment/letters/article/2146722/why-hamassending-children-gaza-conflict-zones

Langer, W. (1999 date of reclassification). A psychological analysis of Adolph Hitler: his life and legend. Office of Strategic Services. Retrieved from https://www.cia.gov/library/readingroom/docs/CIA-RDP7802646R000600240001-5.pdf 
Lipstadt, D. E. (2019). Antisemitism: Here and now. New York, NY: Schocken Books.

Manning, M. J., \& Romerstein, H. (2004). Historical dictionary of American propaganda. Greenwood Publishing Group.

Marcus, I., \& Hirsch, M. (2019, Aug. 18). Palestinian Authority's lies about stabbing terror exposed by footage of attack. United with Israel. Retrieved from https://unitedwithisrael.org/palestinian-authoritys-lies-about-stabbingterror-exposed-by-footage-of-attack/

Mayer, J. (2017). Dark money: The hidden history of the billionaires behind the rise of the radical right. Anchor Books.

Mazzetti, M., \& Benner, K. (2018, July 13). 12 Russian agents indicted in Mueller investigation. The New York Times. Retrieved from https://www.nytimes.com/2018/07/13/us/politics/mueller-indictment-russianintelligence-hacking.html

McDermott, T. (2003, November 7). Arafat's Billions. 60 Minutes. https://www.cbsnews.com/news/arafatsbillions/

Meir-Levi, D. (2007a). The Nazi roots of Palestinian nationalism and Islamic Jihad. David Horowitz Freedom Center.

Meir-Levi, D. (2007b). History upside down: The roots of Palestinian Fascism and the myth of Israeli aggression. Brief Encounters.

Mintz, A. P. (Ed.). (2012). Web of deceit: Misinformation and manipulation in the age of social media. Information Today, Inc.

Mitrokhin, V. (2004). The Mitrokbin archive. Washington, D.C.: The Wilson Center. Available at https://digitalarchive.wilsoncenter.org/collection/52/mitrokhin-archive/4

Morris, L., \& Balousha, H. (2018, April 23). Behind bloody Gaza clashes, economic misery and piles of debt. The Washington Post. Retrieved from https://www.washingtonpost.com/world/middle east/behindbloody-gaza-clashes-economic-misery-and-piles-of-debt/2018/04/23/b4e6476c-3744-11e8-af3c2123715f78df story.html

Mueller, R. S. (2019, March). Report on the investigation into Russian interference in the 2016 presidential election. The United States Department of Justice. Retrieved from https://www.justice.gov/storage/report.pdf

Nahzi, F. (2019 December 19). The West cannot sit by while Russia exploits social media with disinformation. The Hill. Retrieved from https://thehill.com/opinion/international/475797-the-west-cannot-sit-by-whilerussia-exploits-social-media-with

Nance, M. (2016). The plot to hack America: How Putin's cyberspies and Wikileaks tried to elect an American president. New York: Skyhorse Publ.

Nguyen, L. (2019, September 23). Misinformation becoming currency of 'soft power'. Asia Times. Retrieved from https://www.asiatimes.com/2019/09/opinion/misinformation-becoming-currency-of-soft-power/

O'Sullivan, D. (2019 March 11). A lesson in Russian disinformation from the pages of a 1982 TV Guide. CNN Business. Retrieved from https://www.cnn.com/2019/03/11/tech/tv-guide-russiandisinformation/index.html

Obeidat, O. (2014, July 2). Third of Jordan's population lives below poverty line at some point of one year study. The Jordan Times. http://www.jordantimes.com/news/local/third-jordan $\%$ E2 $\% 80 \% 99$ s-populationlives-below-poverty-line-some-point-one-year- $\% \mathrm{E} 2 \% 80 \% 94$-study

PA doubles pay-to-slay salary of terrorist behind murder of three Israeli teens. (2019, July 16). Homeland Security News Wire. Retrieved from http://www.homelandsecuritynewswire.com/dr20190716-pa-doubles-paytoslav-salary-of-terrorist-behind-murder-of-three-israeli-teens

Pacepa, I. M. (2003, September 22). The KGB’s Man. Wall Street Journal. Retrieved from https://www.wsj.com/articles/SB106419296113226300

Pacepa, I. M. (2006, August 24). Russian footprints. National Review, 24. Retrieved from https://www.nationalreview.com/2006/08/russian-footprints-ion-mihai-pacepa/ 


\section{Operation SIG}

Pacepa, I. M, \& Rychiak, R. (2013). Disinformation: Former spy chief reveals secret strategies for undermining freedom, attacking religion, and promoting terrorism. Washington, D.C.: WND books.

Palestinian Authority President Abbas at Jalazone Refugee Camp. (2019, August 21). The Middle East Media Research Institute. Retrieved from https://www.memri.org/reports/palestinian-authority-president-abbas-jalazone-refugee-camp-we-will-enter-jerusalem-millions

Pancevski, B. (2013, Oct 13). £1.95bn EU aid lost in Palestine. The Times. Retrieved from https://www.thetimes.co.uk/article/pound195bn-eu-aid-lost-in-palestine-wwnsk8jc360

Paul, C., \& Matthews, M. (2016). The Russian "Firehose of Falsehood" propaganda model: Why it might work and options to counter it. RAND Corporation. https://doi.org/10.7249/pe198

Pinsker, L. (1882). Auto-emancipation (D. S. Blondheim, Trans). Retrieved from http://www.mideastweb.org/autoemancipation.htm

PLO Calls on UN to Accelerate UNRWA Corruption Probe. (2019, August 17). IMEMC News \& Agencies. Retrieved from https://imemc.org/article/plo-calls-on-un-to-accelerate-unrwa-corruption-probe/

Pomerantsev, P. (2014). How Putin is reinventing warfare. Foreign Policy, 5. Retrieved from https://foreignpolicy.com/2014/05/05/how-putin-is-reinventing-warfare/

Pomerantsev, P. (2019). This is not propaganda: Adventures in the war against reality. PublicAffairs.

Pomerantsev, P., \& Weiss, M. (2014). The menace of unreality: How the Kremlin weaponizes information, culture and money. The Interpreter, a project of the Institute of Modern Russia. Retrieved from https://imrussia.org/media/pdf/Research/Michael Weiss and Peter Pomerantsev The Menace of Unreality.pdf

Poverty in the West Bank and Gaza. (2000). Palestine-Israel Journal, 7(4). Retrieved from https://www.pij.org/articles/264/poverty-in-the-west-bank-and-gaza

The quarter billion dollar question: How is disinformation gaming ad tech? (2019). Global Disinformation Index. Retrieved from https://disinformationindex.org/wp-content/uploads/2019/09/GDI Ad-tech Report Screen AW16.pdf

Romirowsky, A., \& Joffe, A. (2011, April 1). Defund the UNRWA: The 60-year-old U.N. aid agency is keeping Palestinians from leading normal lives. Wall Street Journal. Retrieved from https://www.wsi.com/articles/SB10001424052748704396904576226452357028480

Romirowsky, A., \& Joffe, A. (2019, August 6). The U.N. Agency for Palestinians is even worse than you imagine: A report alleges sexual misconduct, nepotism and retaliation by several UNRWA officials. Wall Street Journal. Retrieved from https://www.wsj.com/articles/the-u-n-agency-for-palestinians-is-even-worse-thanyou-imagine-11565131636

Schoen, F., \& Lamb, C. J. (2012). Deception, disinformation, and strategic communications: How one interagency group made a major difference. National Defense University Press. Retrieved from http://indianstrategicknowledgeonline.com/web/IO\%20Strategic-Perspectives-11.pdf

Shaw, B. (2019, March 20). The ghost of Soviet KGB disinformation within American politics. Canada Free Press. Retrieved from https://canadafreepress.com/article/the-ghost-of-soviet-kgb-disinformation-withinamerican-politics

Shlaim, A (2003, March 29). Dogged by destiny. The Guardian. Retrieved from http://education.guardian.co.uk/higher/books/story/0,10595,924043,00.html.

Sloman, S., \& Fernbach, P. (2018). The knowledge illusion: Why we never think alone. New York, NY. Penguin.

Spinny, L. (2017). The shared past that wasn't. Nature, 543, 168-170. Retrieved from https://www.nature.com/news/polopoly fs/1.21596!/menu/main/topColumns/topLeftColumn/pdf/543168a.pdf

Stan, L. (2013). Transitional justice in post-communist Romania: The politics of memory. Cambridge University Press. Retrieved from http://content.schweitzeronline.de/static/catalog manager/live/media files/representation/zd std orig zd schw orig/004/873 $\angle 566 / 9781107020535$ foreword pdf 1.pdf

Stanley, J. (2015). How propaganda works. Princeton University Press. 
Tabarovsky, I. (2019, May). Soviet anti-zionism and contemporary left antisemitism. Fathom Journal. Retrieved from http:// fathomjournal.org/soviet-anti-zionism-and-contemporary-left-antisemitism/

Tal, E. (1994). Whose Jerusalem? Gefen Books.

Tawil, B. (2019a, August 28). Palestinians: Why allow facts to get in the way? Gatestone Institute International Policy Council. Retrieved from https://www.gatestoneinstitute.org/14782/palestinians-facts-terrorism

Tawil, B. (2019b, September 16). Palestinians' blood libels against Israel, Jews. Gatestone Institute International Policy Council. Retrieved from https://www.gatestoneinstitute.org/14888/palestinians-drugs-blood-libels

Taylor, A. (2016, November 26). Before 'fake news,' there was Soviet 'disinformation'. The Washington Post. Retrieved from https://www.washingtonpost.com/news/worldviews/wp/2016/11/26/before-fake-newsthere-was-soviet-disinformation

Tenenbom, T. (2015a). Catch the Jew! Gefen Publishing House.

Tenenbom, T. (2015b). Interview ‘Catch a Jew’ Reveals Surprising ‘Tribe’ Fueling Hate. CBN. Retrieved from https://www1.cbn.com/cbnnews/insideisrael/2015/June/Catch-a-Jew-Reveals-Surprising-Tribe-FuelingHate

Terrorism and the Soviet Union. (n.d.). In Wikipedia. Retrieved from https://en.wikipedia.org/wiki/Terrorism and the Soviet Union

Thomas, T. (2004). Russia's reflexive control theory and the military. Journal of Slavic Military Studies, 17(2), $237-$ 256. Retrieved from http://impiousdigest.com/wp-content/uploads/2017/08/Thomas 2004.pdf

United Nations Office for Coordination of Humanitarian Affairs. (2018, June 5). 53 per cent of Palestinians in Gaza live in poverty, despite bumanitarian assistance. Retrieved from https://www.ochaopt.org/content/53-centpalestinians-gaza-live-poverty-despite-humanitarian-assistance

Wallace, C. D. (2012). Foundations of the International Legal Rights of the Jenish People and the State of Israel and the Implications for the Proposed New Palestinian State. Creation House. Retrieved from https://books.google.com/books?id=SjXfXifX-ZkC

Wardle, C. (2017). Fake news. It's complicated. First Draft. Retrieved from https://medium.com/1stdraft/fake-news-its-complicated-d0f773766c79

Weingarten, B. (2015, January 22). 5 prominent authors on the parallels between Islam and Communism. The Blaze. Retrieved from https://www.theblaze.com/news/2015/01/22/5-prominent-authors-on-theparallels-between-islam-and-communism

Wilmouth, B. (2019, August 17). Maher slams media for ignoring anti-semitism in Mideast. Media Research Center. Retrieved from https://www.mrctv.org/videos/maher-slams-media-ignoring-anti-semitism-mideast

Woolsey, R. J. (2013, Oct. 23). Book review: Disinformation. Spero News. Retrieved from https://www.speroforum.com/a/HTWNELEQZT35/74505-Book-reviewDisinformation\#.WTCj2t9jM8o

The World Bank Group. (2000). Poverty in the West Bank and Gaza. Palestine-Israel Journal of Politics, Economics, and Culture, 7(4). Retrieved from https://www.pij.org/articles/264

Żaryn, S. (2019, August 9). Russia's hybrid warfare toolkit has more to offer than propaganda. Defense News. Retrieved from https://www.defensenews.com/opinion/commentary/2019/08/09/russias-hybridwarfare-toolkit-has-more-to-offer-than-propaganda/ 


\section{BIOGRAPHIES}
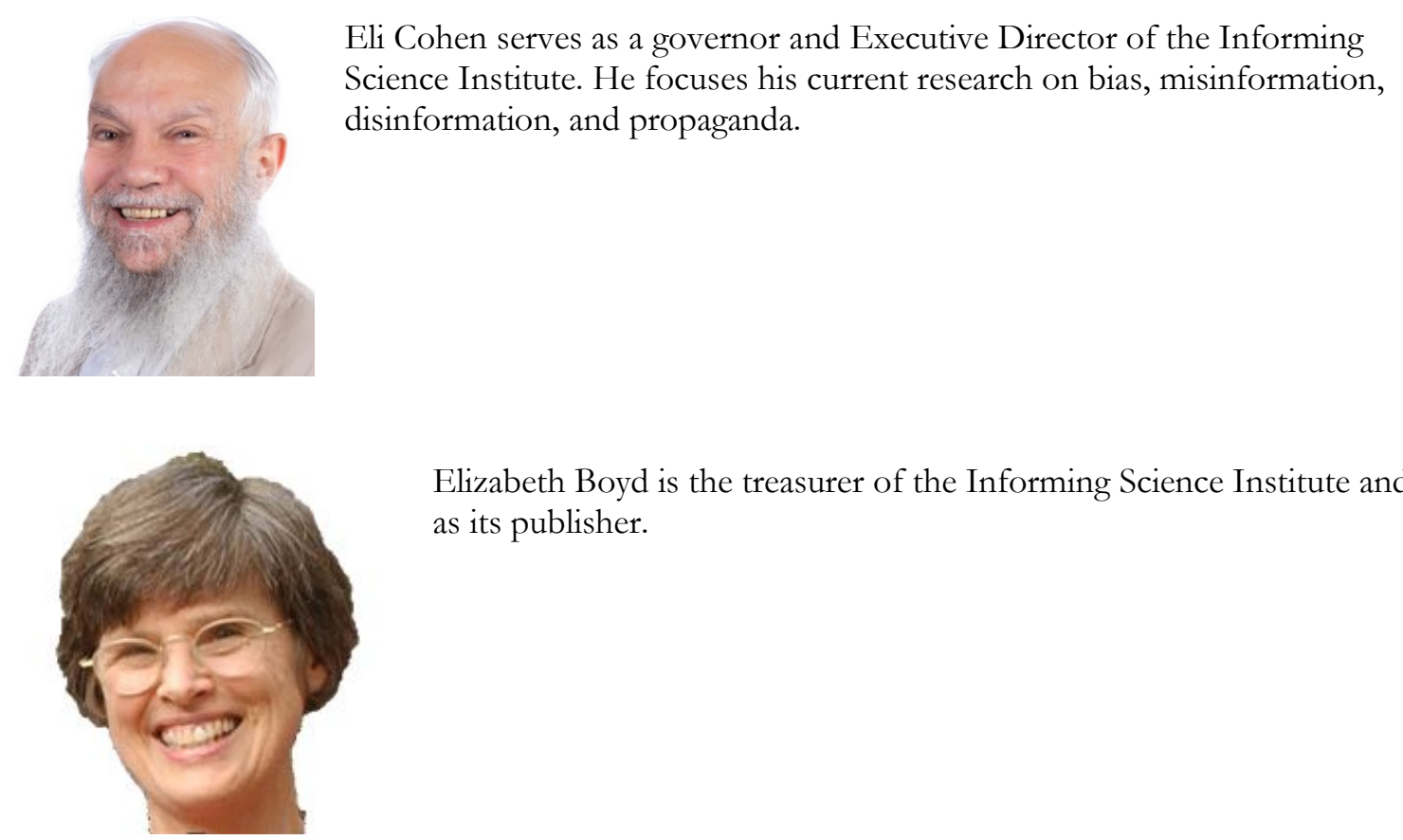

Elizabeth Boyd is the treasurer of the Informing Science Institute and as its publisher. 